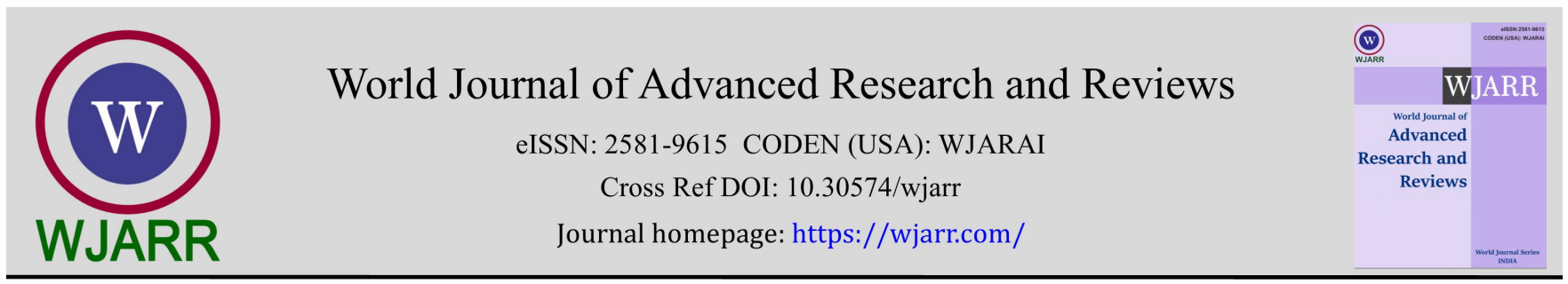

(RESEARCH ARTICLE)

\title{
Impact of government budget deficits on public health sector output in Nigeria
}

\author{
Chinedu Anthony Umeh ${ }^{1,{ }^{*}}$, Chinedu Daniel Ochuba ${ }^{2}$ and Ugochukwu Remigius Ihezie ${ }^{3}$ \\ ${ }^{1}$ Department of Economics, Enugu State University of Science and Technology. \\ ${ }^{2}$ School of Business Education, Federal College of Education (Technical) Umunze. \\ ${ }^{3}$ Department of Social Science (Economic Unit), Federal Polytechnic Nekede Owerri.
}

World Journal of Advanced Research and Reviews, 2021, 11(02), 350-364

Publication history: Received on 21 July 2021; revised on 25 August 2021; accepted on 27 August 2021

Article DOI: https://doi.org/10.30574/wjarr.2021.11.2.0403

\begin{abstract}
The study examined the impact of government budget deficits on the public health sector output in Nigeria over a period of 1980 to 2018. The specifically study sought to: investigate the impact of government budget deficits affect the public health sector output in Nigeria, ascertain the impact of external borrowing on the public health sector output in Nigeria and evaluate the impact of domestic borrowing budget deficits financing on the public health sector output in Nigeria. The methods of data analysis range from argument dickey fuller unit root test, Johansen co-integration test and finally error correction method. The following results were the basic findings of the study: (1) government budget deficits have positive insignificant impact on public health sector output in Nigeria ( $t$ - statistics $(0.5663)<t 0.05$ (1.684); (2) external borrowing of financing budget deficits has negative insignificant impact on Health sector output in Nigeria ( $\mathrm{t}$ - statistics $(-1.2746)<t 0.05(1.684)$ and (3) domestic borrowing of financing budget deficits has positive significant impact on Health sector output in Nigeria $(\mathrm{t}$ - statistics $(2.1711)>t 0.05$ (1.684). This study concludes that the budget deficits of government have positive insignificant impact on Health sector output in Nigeria because more budget allocations are put in health recurrent government expenditure than health capital expenditure whereas health capital expenditure is the engine of growth in health sector output. The study recommended that the Federal Government should commence and continue to execute the National Health Act. Allocation's map-out for the Basic Health Care Provision Fund (BHCPF) should be drawn directly from the National Health Act, which is not less than 1\% of the Consolidated Revenue (CRF) Fund of the Federation and is to flow from the FG's share of revenue.
\end{abstract}

Keywords: Government Budget Deficits; Health Sector Output; External Borrowing Budget deficits financing; Domestic Borrowing Budget deficits finance

\section{Background of the Study}

The Nigeria government has been committed to a stable macroeconomic environment, characterized by low and stable inflation and sound fiscal policy. Starting from 1970s to date, the government of Nigeria has been going through great, prolong and inconsistent budget deficits. Regardless of all socio-economic public policy employed in most recent time which emphasized appropriate management through fiscal policy. Nigeria economy is characterized with budget deficit coupled with a stunted economic growth. The primary danger of a budget deficit is inflation, which is the continuous increase of price levels. In the Nigeria, a budget deficit always causes the Nigeria monetary authority to release more money into the economy on the account to feed inflation. Consistent budget deficits can lead to inflationary monetary policies on yearly bases [1].

Empirical studies of scholars have proved that government budget deficit always result to the need for reduction in expenditure of government in near time. Higher government deficits are not sustainable forever. A decrease budget

\footnotetext{
* Corresponding author: Umeh Anthony Chinedu

Department of Economics, Enugu State University of Science and Technology.
}

Copyright (c) 2021 Author(s) retain the copyright of this article. This article is published under the terms of the Creative Commons Attribution Liscense 4.0. 
deficit can result to problem. This budget deficit reduction caused lower growth, a fall in aggregate demand, recession and unemployment [1,2]. Again, studies have showed that couple of both developed and developing country has entered into national debt, increase cost of public borrowing interest payment and potential increase in bond rate of return as a result of government budget deficit policy. Large budget deficits may result to national debt and also increases GDP by one percent. A high budget deficit may result to proportionate increase in national income through debt services payments. Countries with large government budget deficits may struggle to attract sufficient investors to buy bonds. On account of this, bond yields will rise causing the deficit to be more expensive to finance $[3,4,5]$.

A promotion in health status of the nation's citizens is an essential precondition for attaining development in human capital. Good health status of citizens has multiplier effect in efficient, productive and skillfulness in human capital which may cause economic development. Despite this snail-improvement in health spending, the country still lagged behind compared to other countries in the continent. Statistics have shown that the country's public expenditure on health as a percentage of GDP is 4.1 percent instead of 4.6 percent in Africa countries on average and over 6.3 percent in developed countries. With help of this statistic, overall health status in Nigeria has not been well encouraging. Yaqub, Ojapinwa and Yussuff, [6] note that the country overall health performance was ranked 187th among the 191 Member States by the World Health Organisation. This may imply that budget deficits do not support health sector output in Nigeria.

\section{Statement of the Problem}

On the account of small government expenditure allocates to Nigeria health sector out of large government budget deficits practice year by year, the health status in Nigeria is ranked low among other developing country in the similar grouping. Life expectancy is put at 52 years in 2011(according to World Bank) and crude death rate, in that same year as $14 \%$. It is approximated that 124 out of 1000 new births do not survive beyond age of five years. Only $39.56 \%$ of male and $42.25 \%$ of female survive up to the age of 65 years. There are close to 3 million adults (ages 15-49) living with HIV. While the estimated HIV/AIDS prevalence rate is 3.7. Nigerians that are in health workforce are equivalent to that of Egypt and South Africa who are in health workforce but child mortality is high in Nigeria at 51 percent due to unskilled health personnel [7].

The expenditure pattern shows that only few amounts are spent on health in Nigeria. In 1997, 4.6\% of gross domestic product (GDP) is accounted to have been spent on health care. The figure rose to $6.6 \%$ in 2005 and later fell to 5.8 in 2009. The actual total expenditure starting from 1997 till date shows a sign of reduced commitment of Nigeria government to promote health service deliveries. Available Statistical data shows the pocket expenditure constitutes higher proportion of total health expenditure. Public expenditure on health (PHE) was $36.7 \%$ of the total health expenditure in 2011 while out of pocket expenditure amounts to $60.4 \%$ of the total expenditure [7].

While the agitating for more budgetary funds from government budget deficit for greater output of health sector, the very little federal allocated funds get misappropriated at the point of budget implementation. In-addition, the budgetary allocation for health sector hardly gets to the target layers envisaged during budget implementation. Most of these funds get embezzled by corrupt officials and their collaborating suppliers and contractors [8]. The federal allocation for the health sector in Nigeria is pathetic because there is no infrastructure to do the most fundamental necessities such as steady power for hospital equipment (where available), good roads to transport patients to and from the hospitals, emergency medical service and personnel (if you dial 911, you're on your own), or even water for proper sanitation. The wards in some of the hospitals are so run down and bare they look like they would be sources for new outbreaks of diseases. The absence of modern facilities in many public hospitals in Nigeria is linked to failure of successive governments to pay adequate attention to the health sector. Therefore, it is in the light of this that this study will examine the impact of government budget deficits on public health sector output in Nigeria. The specific objectives are to:

- Investigate the impact of government budget deficits affect the public health sector output in Nigeria.

- Ascertain the impact of external borrowing budget deficits financing on the public health sector output in Nigeria.

- Evaluate the impact of domestic borrowing budget deficits financing on the public health sector output in Nigeria.

\section{Budget Deficit}

Budget deficit is regarded as a deficit in a country's estimated budget where income from taxation will not be sufficient to pay for the government's expenditure and sought for other source of financing Anyanwaokoro [9] defined deficit 
budgeting as government that intends to expend much more money than it earns from diverse income sources. Budget deficit is also called national debt, when referring to federal government accrued deficits.

In addition, Maji and Achegbulu [10] define budget deficit in terms of loan financing and drawing down of cash balances, which implies the difference between the budget receipts and budget expenditures funded by withdrawal of cash balance and borrowing from public. The concept is perceived as a sign of financial health in which government expenditures fall short of its revenues over a given time.

Budget Deficit or Fiscal Deficit: This refers to the practice whereby the government spends more money that it receives within the fiscal year. The gap between the revenue and expenditure profile of the government is either bridged by borrowing or supply of new money (hot money) into the economy. Budget deficit may be attributed to a number of reasons but basically it derives from a deliberate effort of the government to stimulate the economy by either lowering the tax rate or increasing its expenditure [11].

\section{Theoretical Literature}

\section{Keynesian theory of budget deficit and fiscal policy}

Keynesian theory of budget deficit and fiscal policy economics developed in the 1930s offering a response to the unique challenges of the Great Depression. Keynesian economics entails: government intervention to stabilise the business/trade cycle using expansionary fiscal policy which involves cutting tax and increasing spending. The expansionary fiscal policy is what Keynesian economics suggested to speed up economic recovery, during the great depression of the 1930s. the existing economic theory was unable either to explain the causes of the severe worldwide economic collapse or to provide an adequate public policy solution to jump-start production and employment.

British economist John Maynard Keynes changed the classical economic thinking that is characterize with prevailing idea that free markets which automatically provide full employment-that is that everyone who wanted a job would have one by working at a prevailing wage rate. The central idea of Keynes's theory is that what caused the business cycle was lack of effective demand-meaning as the sum of spending by households, businesses, and the governmentis the great essential driving force in an economy. Keynes further asserted that forces of demand and supply have no self-balancing devices that lead to full employment. Keynesian economists defend government intervention through fiscal policies as only way to attain price stability and full employment.

\section{Empirical Review}

Ayadi and Ayadi, [12] examined the impact of the huge budget deficit on economic performance of the Nigerian and South African economies. Specially, the study sought to; (i) evaluate the impact of debt servicing requirement on the economic performance of Nigeria and South Africa. The model established in the study was estimated using econometric techniques such as Augmented Dickey-Fuller test, Granger causality test, Johansen co-integration test and Vector Error Correction Method (VECM). Their findings revealed that debt and its servicing requirement has a negative impact on the economic performance of Nigeria and South Africa. The results revealed that causality does not exist between budget deficit and economic performance in Nigeria.

Kosimbei, [13] studied the relationship between budget deficit on macroeconomic performance in Kenya. The study was based on the Mundel-Fleming model, and adopted the Vector Autoregressions (VARs) as well as the yearly time series data covering 1963 - 2007. The selected macroeconomic variables involved current account of the balance of payments, private consumption, private investments, money supply, treasury bill rates and real GDP. The results showed that budget deficits had a significant effect on private consumption, private investments, money supply (M3), treasury bills rate, current account and real GDP.

Ogunmuyiwa, [14] examined whether budget deficit promotes economic performance in Nigeria using time-series data from 1970-2007. The regression method was estimated using econometric techniques such as Augmented DickeyFuller test, Granger causality test, Johansen co-integration test and Vector Error Correction Method (VECM). The results revealed that causality does not exist between budget deficit and economic performance in Nigeria.

Saeidi and Valizadeh, [15] examined impact of budget deficits on inflation and unemployment in Iran's economy. The theoretical foundation of the study was the Keynesian hypothesis. OLS and LS square were used to estimate the parameters contained in the three models adopted by the researchers to measure the impact of each independent 
variable on dependent ones. The results revealed that budget deficit had a positive influence on inflation and unemployment in Iran. The implication is that Keynesian theory is prevalent in Iran's economy. The authors concluded that general price levels, inflation and unemployment rates remained critical variables of macroeconomy, which promoted growth. They added that sound policy making guaranteed desirable rate of inflation and unemployment, stressing that budget constituted the primary instrument available to government for policy making.

Ekperiware and Oladeji, [16] examined the structural break relationship between budget deficit and economic performance in Nigeria. The study employed a quarterly time series data of budget deficit, budget deficit service and real GDP from 1980-2009. An empirical investigation was conducted using the chow test method of estimation to determine the structural break effect of budget deficit on economic performance in Nigeria as a result of the 2005 Paris Club debt relief. The result of their findings revealed that the 2005 budget deficit relief caused a structural break effect in the relationship between budget deficit and economic performance.

Suliman and Azeez, [17] studied the effect of budget deficit on the economic performance of Nigeria using Annual time series data spanning from 1970-2010. The empirical analysis was carried out using econometric techniques of Ordinary least squares (OLS), Augmented Dickey-Fuller unit root test, Johansen Co-integration test and error correction method. The co-integration test shows long-run relationship amongst the variables and findings from the error correction model revealed that budget deficit as contributed positively to performance of the Nigerian economy. They hence recommend that political and economic stability should be embraced to ensure effective debt management.

Faraji and Makame, [18] investigated the impact of budget deficit on the economic performance of Tanzania covering the period 1990-2010. It was observed through the Johansen co-integration test that no long-run relationship existed between budget deficit and GDP. However, the findings show that budget deficit and debt service both have significant impact on GDP performance with the total budget deficit stock having a positive effect of about 0.36939 and debt service payment having a negative effect of about 28.517 .

Joseph and Uma [19] empirically examine the nexus between interest rate and budget deficit in the context of Nigeria applying error correction model (VECM) Spanning from 1970 to 2010. From the findings it was discover that budget deficit has a positive and significant impact on interest rate in the long run implying that rising interest rate occur as a result of higher budget deficit hereby canvassing support for the Keynesian proposition. Sequel to this, the researcher postulate that appropriate monetary -fiscal policies mix should be put in place.

Wosowei [20] studied the relationship between fiscal deficit and macroeconomic performance in Nigeria over the period 1989 - 2010. Specifically, the paper examined the following objectives: to explore the influence of fiscal deficit on macroeconomic aggregates in Nigeria, and to investigate whether fiscal deficit had influenced economic growth in Nigeria, among others employing data secondary in nature. OLS method was used to estimate the variables. However, the findings showed that fiscal deficits even though that it satisfied the economic a prior in terms of its negative coefficients, yet did not significantly affect macroeconomic output. The result also showed a bilateral causality relationship between government deficit and gross domestic product, government tax, and unemployment, while there was an independent relationship between government deficit, government expenditure and inflation.

Umeora, [21] analyzed the relationship between fiscal deficits and selected macroeconomic variables (such as gross domestic product, exchange rate, inflation rate, money supply and lending interest rate in Nigeria covering the period 1970 - 2011. OLS method was used to analyze the relationships. Relevant data were sourced from the CBN Statistical Bulletin. The findings included, that fiscal deficit related positively and significantly with gross domestic product, exchange rate, inflation rate and money supply, and that fiscal deficit related negatively with lending interest rate.

Onuorah and Ogbonna [22] investigated effect of deficit financing on economic growth in Nigeria using data contained in the Annual Report and Statement of Account and Statistical Bulletin of the Central Bank of Nigeria (CBN) for the period 1981 - 2012. The paper applied descriptive statistics, OLS econometric method, diagnostic test, ADF unit root test and Johansen Co-integration test, as well as Pair- wise Granger causality test as techniques of analysis. The variables were jointly co-integrated at 5\% level. This implied that deficit financing were statistically significant and positively related to economic growth in Nigeria. This meant that both domestic debt and external debt liability contributed effectively to the liquidation of our debt stock within the sampled period. Based on the regression result, it is clear that the country's domestic debt and foreign debt constituted a veritable instrument of finance in Nigeria. The study therefore concluded that a long-run equilibrium connection occurred between the dependent and independent variables. This means that deficit financing exerted substantial influence on the growth cum debt management and debt services in Nigeria. 
Vincent and Clem [5] examined the crowding-out effect of budget deficits on private sector investments within the Nigerian context, using data for the period of 1970 to 2006. The result indicated that budget deficits had a depressive effect on private investment in the country. The estimation results suggest that a $1 \%$ increase in fiscal deficit leads to $0.267 \%$ decline in private investment. The results also indicate that Nigeria's debt profile has had strong and negative impact on private investment in Nigeria.

Odhiambo, Momanyi, Othuon and Aila, [23] conducted a study to establish the extent to which fiscal deficits and economic growth are related and further investigated ways in which fiscal deficits (transmission mechanism) have effects on the growth and development of the Kenyan economy. The study used both exploratory and causal research designs and employed time series secondary data for a period of 38 years (1970-2007). The method of data analysis was OLS method. The study showed positive relationship between budget deficits and economic growth. The finding is in line with the Keynesians assertion and hence recommends judicious financial management and revenue authority should enhance revenue collection to avoid crowd-out private sector investment by borrowing internally.

Ojong, Owuiz and Effiong [24] examined effect of budget financing on economic development in Nigeria. Annual time series secondary in nature spanning over the period 1980 - 2008 were sourced from the CBN Statistical Bulletin. Six research hypotheses developed to assess the relationship between budget deficit financing, unemployment, inflation rate, balance of payment, government financing, government revenue, which formed the explanatory variables, while GDP was used as dependent variable. OLS econometric method was used to estimate equations specified for the study. The results proved as follows that: (i) there existed a significant connection budget deficit financing and economic growth, (ii) an inverse relationship occurred between GDP and unemployment, (iii) a direct relationship showed between GDP and inflation rate, (iv) a significant relationship was observed between GDP and government expenditure, (v) an inverse relationship occurred between GDP and government revenue.

Osuka and Achinihu, [25] investigated impact of budget deficits on macroeconomic variables in Nigeria stretching the period 1981 - 2012. The researchers conducted preliminary test using ADF method to ascertain stationarity of the variables, which were stationary (absence of unit root) at first differencing. The Granger Causality results indicated a unidirectional causal relationship between Budget deficits and GDP with GDP granger causing budget deficit. Conversely, the test for causality further revealed absence of causality between deficits and interest rate, budget deficits and inflation and budget deficit and nominal exchange rate. Based on the results, the study concluded that budget deficits impacted significantly on the macroeconomic behaviour of the Nigerian economy within the period studied.

Nkalu [26] examined the effects of budget deficits on selected macroeconomic variables in Nigeria and Ghana employing annual time-series data of the two countries spanning from 1970 to 2013. The specific objectives of the study include: to determine the impact of budget deficits on inflation rate, interest rate and economic growth in Nigeria and Ghana. The method of data analysis were Seemingly Unrelated Regression (SUR) model and Two-Stage Least Squares (2SLS). The findings showed that budget deficit impacted negatively on inflation rate, interest rate and economic growth thereby affirming the neoclassical position in the literature that budget deficit impedes growth and crowd-out private investment in the economy.

Agu, Okwo, Ugwunta and Idike, [27] conducted a study with aim at determining the impact of various components of fiscal deficits on the Nigerian economy. The study used descriptive statistics to show contribution of government fiscal policy to economic growth, and to ascertain and explain growth rates, and an ordinary least square (OLS) in a multiple form to ascertain the relationship between economic growth and government expenditure components after ensuring data stationarity. Findings revealed that total government expenditures have tended to increase with government revenue, with expenditures peaking faster than revenue. Investment expenditures were much lower than recurrent expenditures evidencing the poor growth in the country's economy. Hence, there is some evidence of positive correlation between government expenditure on economic services and economic growth.

Osoro, [28] sought to examine the relationship between budget deficit and economic growth in Kenya using time series data for the period 1980 to 2014. The study employed Ordinary Least Squares (OLS) method of estimation. The results indicate a positive relationship between budget deficit and economic growth but as the budget deficit increases, the impact on growth decreases. The study identified a budget deficit of approximately 4 per cent of Gross Domestic Product (GDP) as being optimal for the case of Kenya economy, beyond this level, the benefits obtained from the deficits start diminishing. This result supports the Keynesian view of budget deficit which advocates for deficit in stimulating the economy during recession periods.

Momodu and Monogbe, [29] sought to examine the lag effect of previous year's budget deficit on performance of the Nigeria economy in the contemporary year using VAR estimation between the periods 1981 to 2015. From the foregoing 
statistical output, findings established that Budget deficit significantly stimulate economic performance. The output of the granger causality test shows that budget deficit statistically granger cause economic performance and viz versa while the result of the multiple regression of the ordinary least square report a significant but negative relationship to economic performance. The negative response of budget deficit to economic performance could be attributed to moral hazard, mismanagement of fund and financial indiscipline which prevent the country from enjoying the sustainable level of expected growth overtime. The output of the VAR estimate established that the lag value of federal government budget deficit has contributed to performance of the economy in the current year although the contributive quadrant is not been felt to a reasonable extent. These empirical findings support the Keynesian postulation of significant relationship between budget deficit and economic performance.

Nwaeze, [30] examined empirically the relationship between fiscal deficits and macroeconomic stability in Nigeria from 1970 to 2016. The study employed descriptive statistics, unit root test, cointegration and VAR estimation methods to analyze the data. The results of the variance decomposition reveal that Interest rate (INTR), overall fiscal deficits (OFDE) and the size of fiscal deficits financed by domestic borrowing (DBFD) are the main shocks causing the variation in inflation (INFL), while overall fiscal deficits (OFDE), the size of fiscal deficits financed by external borrowing (EBFD) and the size of fiscal deficits financed by domestic borrowing (DBFD) are the main shocks causing the variation in exchange rate (EXCR) in Nigeria. The study concludes that fiscal deficits have significant negative impact on macroeconomic stability vis-a-viz inflation and exchange rates in Nigeria.

Dantama, Gatawa and Galli, [31] examined the long run impact of fiscal deficit on private investment employing annual time series data covering the period of 1980 to 2014. A modeling approach that incorporates ADF and PP for unit root test, Johansen cointegration test and Error Correction Model (ECM) were employed. The unit root test revealed that both the series exhibit unit root at the level value and became stationary after differencing of order one that is I(1) while the result of Johansen suggest one coingration vector at 5\% significant level. The ECMt-1 result indicates that 38\% numbers of errors have been corrected from short run adjustment to the long run. It further proves that a unit increase in fiscal deficit, government revenue and exchange rate crowd in private investment by $0.0003,0.276$ and 0.205 respectively while a unit increases in government expenditure crowd out private investment by -0.570 percent in the long run.

Ayogueze and Anidiobu, [32] assessed the impact of government budget deficits on unemployment rate in Nigeria over the sampled period of 1986 to 2015. This study employed the ex-post facto research design. Ordinary Least Square (OLS) econometric technique was used to estimate the variables. Decisions were made based on a five per cent level of significance. The empirical results indicated that government budget deficit had a positive and non-significant impact on unemployment rate in Nigeria within the period under review. This study suggested that expansionary fiscal policy should be encouraged since it hastened development process of the economy.

Tung, [2] examined the effect of fiscal deficit on economic growth in Vietnam. The study has applied the Error Correction model on the quarterly data of 2003-2016. The empirical results strongly indicate there is a cointegration relationship between fiscal deficit and economic growth in Vietnam, in which fiscal deficit had harmful effects on economic growth in both short and long run. In particular, the correlation analysis has confirmed that fiscal deficit can hurt not only the gross output but also private investments, foreign direct investments, and net exports. Our results provide evidence for policymakers, and not only in Vietnam but also in other emerging countries which are in need of urgent solutions so that to reduce the fiscal deficit rate and have more sustainable growth in the future.

Ubi and Inyang [4] made use of content analysis to examine effect of fiscal deficit on Nigeria's economic development from 1980 to 2016. It was observed that Nigeria's fiscal operations for about 37 years had resulted in deficit in 35 years and surpluses for only two years. Surprisingly, the increasing fiscal deficit had been skewed in favour of recurrent expenditure at the expense of capital expenditure. It was discovered that Nigeria's fiscal deficit has contributed positively to the growth of per capita income, economic growth and stabilization of Balance of payments only. Fiscal deficit did not reduce unemployment and inflation rates within the period of study.

Oluwafadekemi and Ogundipe, [1] investigated the effects of fiscal deficits on Nigeria economic growth from 19812014. The study established an optimal fiscal deficit level using the Threshold Autoregressive model. The empirical analysis supported the existence of a significant positive relationship between economic growth and the regressors capital, labour, inflation rate, and trade openness. On the other hand, the study found that a significant negative relationship exists between fiscal deficits, financial depth and economic growth in Nigeria. The study established a threshold level of $5 \%$ which is conducive for economic growth at a lag of 1 year, for the Nigerian economy. Aligning this finding to the present reality, it is hence concluded that the Nigerian economy has been characterized by continuous fiscal deficits, which has not positively contributed to economic growth. 
Behera and Dash, [33] examined the impact of macroeconomic policies on the growth of public health expenditure over a period of 1990 to 2014. The study examines the dynamic relationships between public health expenditure and macroeconomic factors (economic growth, domestic revenue, domestic debt, fiscal balance, and central government transfer) of 15 major states of India. Our empirical result shows that state's revenue (i.e. tax revenue and indirect tax) and central transfer (i.e. tax devolution) are the major public providers for financing the health care of Indian states. Other sources of revenue of the government, namely non-tax revenue and direct tax show no impact on public health expenditure in the short run, while it shows a positive impact in the long run. As a consequence, we find that economic growth and fiscal balance lead to a favorable impact on public health expenditure in the long run.

Jibir and Aluthge, [34] conducted a study to examine the determinants of government expenditure in Nigeria. The study employs a slightly modified version of Wagner's law by incorporating new variables such as oil revenue, trade openness, public debt, exchange rate, oil price, taxation and inflation. The study uses time series data for Nigeria spanning between 1970 and 2017. Time series data were analysed using Autoregressive Distributed Lag (ARDL) model. The findings of the study reveal that oil revenue, GDP, population, trade openness, oil price, taxation and inflation are important determinants of the size of Nigeria's government expenditure.

Nwanna and Umeh, [35] examined the effect of budget deficit finance on Nigeria economic growth covering a period of 1981-2016. Augmented Dickey Fuller (ADF) unit root test, Johanson Co-integration test and normality test were employed for the analysis. The research findings revealed that deficit financing through External debt borrowing has a significant negative effect on Nigeria's economic growth. Also Domestic debt has a positive significant effect on Nigeria's economic growth, while Debt service has no significant effect on Nigeria's economic growth. The study therefore, recommends that Government should set up monitoring teams that will make sure that the budget is well and carefully implemented and as well as loan borrowed in other to reduce corruption, linkages and wastages, the team will do this by holding everyone accountable for every kobo of government money spent.

\section{Methodology}

This study made use of expost-facto research design which enables us to measure the effect or relationship between dependence variable and explanatory variables using time-series secondary data. To empirically examine the impact of government budget deficits on the health sector output in Nigeria, the researcher subjected the data collected to Augmented Dickey-Fuller Unit Root test statistic, Johansen Co-integration test, error-correction mechanism, BreuchGodfrey Serial Correlation LM Test and Ramsey Reset.

\subsection{Data Sources}

To investigate how government budget deficits could affect health sector output in Nigeria, a number of variables have been taken into consideration in this study. These variables consist of Health sector GDP (HGDP), Health Recurrent Expenditure (HARE), Health Capital Expenditure (HECE), Domestic borrowing Finance (DOBF), External borrowing finance (EXBF), and Term of Trade (TOT) for the period of 1980-2018 and are defined in our model specification. All the variables were sourced from Central Bank of Nigeria's (CBN) statistical bulletin for various years.

\section{Model Specification}

The study adopts the work of Keynesian framework. In a simple Keynesian framework, the desired aggregate demand relationship in the Keynesian framework is expressed as follows:

$\mathrm{Y}=\mathrm{C}+\mathrm{I}+\mathrm{G}+(\mathrm{X}-\mathrm{M})$ Eqn 3.2 .1

This study specifically adopts the model of Onuorah and Ogbonna [22]; Osoro, [28] to study of the impact of government budget deficit on Economic growth. Thus, the model is represented in a functional form as shown below:

\subsection{HGDP=f (GOBD, HARE, HECE, DOBF, EXBF, TOT)}

Eqn 3.3.1

Where HGDP is Health sector GDP, HARE is Health Recurrent Expenditure, HECE is Health Capital Expenditure, DOBF is Domestic borrowing Finance, EXBF is External borrowing finance, and TOT is Term of Trade.

In a linear function, it is represented as follows:

$\mathrm{HGDP}=\beta_{0}-\beta_{1} \mathrm{GOBD}-\beta_{2} \mathrm{HARE}+\beta_{3} \mathrm{HECE}+\beta_{4} \mathrm{DOBF}+\beta_{5} \mathrm{EXBF}+\beta_{6} \mathrm{TOT}+\mathrm{Ut} . . \mathrm{Eqn} 3.3 .2$ 
Where: $\beta 0=$ Constant term, $\beta_{1}$ to $\beta_{4}=$ Regression coefficient and Ut $=$ Error Term.

To reduce the outliers among the variables, all variables will be expressed in logarithmic form.

HGDP $=\beta_{0}-\beta_{1} \operatorname{LogGOBD}-\beta_{2}$ LogHARE $+\beta_{3} \operatorname{LogHECE}+\beta_{4} \operatorname{LogDOBF}+\beta_{5} \operatorname{LogEXBF}+\beta_{6}$ LogTOT + Ut. Eqn 3.3.2

Where: $\beta 0=$ Constant term, $\beta_{1}$ to $\beta_{6}=$ Regression coefficient and Ut $=$ Error Term.

\section{Results and Discussion}

It has been shown in econometric studies that most macroeconomic time series are not stationary at levels. Giving this knowledge, testing for stationarity of variables to obtain a more reliable result becomes very essential. Stationarity test was therefore carried out using Augmented Dickey-Fuller (ADF) approaches for unit root testing which are reported in table 1 . In order to examine the unit root status of the variables.

Table 1 Results of Stationarity (unit root) test

\begin{tabular}{|c|c|c|c|}
\hline Variables & ADF- Statistics & Critical Value & Order of integration \\
\hline HGDP & -5.817708 & $\begin{array}{c}1 \% \text { level }=-3.621023 \\
5 \% \text { level }=-2.963427 \\
10 \% \text { level }=-2.610263\end{array}$ & Stationary first difference (1) \\
\hline GOBD & -6.454584 & $\begin{array}{c}1 \% \text { level }=-3.621023 \\
5 \% \text { level }=-2.963427 \\
10 \% \text { level }=-2.610263\end{array}$ & Stationary first difference (1) \\
\hline HARE & -4.912954 & $\begin{array}{c}1 \% \text { level }=-3.621023 \\
5 \% \text { level }=-2.963427 \\
10 \% \text { level }=-2.610263\end{array}$ & Stationary first difference (1) \\
\hline HECE & -6.543014 & $\begin{array}{c}1 \% \text { level }=-3.621023 \\
5 \% \text { level }=-2.963427 \\
10 \% \text { level }=-2.610263\end{array}$ & Stationary first difference (1) \\
\hline DOBF & -6.115310 & $\begin{array}{c}1 \% \text { level }=-3.621023 \\
5 \% \text { level }=-2.963427 \\
10 \% \text { level }=-2.610263\end{array}$ & Stationary first difference (1) \\
\hline EXBF & -4.903364 & $\begin{array}{c}1 \% \text { level }=-3.621023 \\
5 \% \text { level }=-2.963427 \\
10 \% \text { level }=-2.610263\end{array}$ & Stationary first difference (1) \\
\hline TOT & -5.263429 & $\begin{array}{c}1 \% \text { level }=-3.621023 \\
5 \% \text { level }=-2.963427 \\
10 \% \text { level }=-2.610263\end{array}$ & Stationary first difference (1) \\
\hline
\end{tabular}

The results of the stationarity (unit root) test indicate that Health sector GDP (HGDP), Health Recurrent Expenditure (HARE), Health Capital Expenditure (HECE), Domestic borrowing Finance (DOBF), External borrowing finance (EXBF), and Term of Trade (TOT) were stationary at first difference. It is now referable to use Error Correction regression Model to estimate the parameters.

\subsection{Co-integration Test Results}

Since all the variables were integrated of order 1 (1), we turned to determine the existence of long run equilibrium relationship between the variables. Separate co-integration tests were carried out on Health sector GDP (HGDP), government budget deficits (GOBD), Health recurrent expenditure (HARE), Health capital expenditure (HECE), Domestic borrowing financing (DOBF), External borrowing financing (EXBF) and Term of trade (TOT). 
Non-stationary time-series can be co-integrated if there are linear combinations of them that are stationary, that is, the combination does not have a stochastic trend. In other words, if two or more I(1) variables are cointegrated, they must obey an equilibrium relationship in the long-run, although they may diverge substantially from that equilibrium in the short run. The co-integration tests are based on the Johansen and Juselius (1989) test. Tables 5 and 6 present the cointegration test results.

Ho $=$ There is no co-integration (no long run relationship among Variable)

Table 2 Co-integration Test Results

\begin{tabular}{|c|c|c|c|c|}
\hline \multicolumn{5}{|c|}{ Date: $01 / 10 / 20$ Time: $13: 06$} \\
\hline \multicolumn{5}{|c|}{ Sample (adjusted): 19822018} \\
\hline \multicolumn{5}{|c|}{ Included observations: 37 after adjustments } \\
\hline \multicolumn{5}{|c|}{ Trend assumption: Linear deterministic trend } \\
\hline \multicolumn{5}{|c|}{ Series: HGDP GOBD HARE HECE DOBF EXBF TOT } \\
\hline \multicolumn{5}{|c|}{ Lags interval (in first differences): 1 to 1} \\
\hline \multicolumn{5}{|c|}{ Unrestricted Cointegration Rank Test (Trace) } \\
\hline Hypothesized & & Trace & 0.05 & \\
\hline No. of CE(s) & Eigenvalue & Statistic & Critical Value & Prob.** \\
\hline None* & 0.999913 & 777.4969 & 125.6154 & 0.0001 \\
\hline At most $1 *$ & 0.991259 & 431.5138 & 95.75366 & 0.0001 \\
\hline At most $2 *$ & 0.922118 & 256.1435 & 69.81889 & 0.0000 \\
\hline At most $3 *$ & 0.898512 & 161.6989 & 47.85613 & 0.0000 \\
\hline At most $4^{*}$ & 0.692733 & 77.04977 & 29.79707 & 0.0000 \\
\hline At most $5 *$ & 0.587503 & 33.38838 & 15.49471 & 0.0000 \\
\hline At most 6 & 0.016720 & 0.623888 & 3.841466 & 0.4296 \\
\hline \multicolumn{5}{|c|}{ Trace test indicates 6 cointegrating eqn(s) at the 0.05 level } \\
\hline \multicolumn{5}{|c|}{$*$ denotes rejection of the hypothesis at the 0.05 level } \\
\hline **MacKinnon- & g-Michelis ( & 9) p-values & & \\
\hline
\end{tabular}

The co-integration results in table 1 for the model (HGDP, GOBD, HARE, HECE, DOBF, EXBF, TOT) reveals that both trace test and the Max-eigenvalue test indicates 6 co-integrating equation(s) at the 5 percent level of significance. Thus there is a long-run relationship among the variables (HGDP, GOBD, HARE, HECE, DOBF, EXBF, TOT). We therefore reject the null hypothesis of no co-integration amongst the variables and accept the alternative hypothesis.

\subsection{Estimation of Regression Model}

The error correction model was carried out to examine parameters estimates. In testing this hypothesis, government budget deficits (GOBD), Health recurrent expenditure (HARE), Health capital expenditure (HECE), Domestic borrowing financing (DOBF), External borrowing financing (EXBF) and Term of trade (TOT) were regressed against Health sector GDP (HGDP). The result of the regression analysis represents the model for the impact of government budget deficits on public health sector output. The empirical result shows that the coefficient of government budget deficits (GOBD) has positive insignificant impact on Health sector GDP (HGDP) because observed values of $t$ - statistics (0.5663) was less than its critical value (1.684). The empirical result shows that the coefficient of Health recurrent expenditure (HARE) has positive significant impact on Health sector GDP (HGDP) because observed values of $t$ - statistics (2.6820) was greater than its critical value (1.684). The empirical result shows that the coefficient of Health capital expenditure (HECE) has positive insignificant impact on Health sector GDP (HGDP) because observed values of $\mathrm{t}-\mathrm{statistics}$ (1.0022) was less than its critical value (1.684). The Domestic borrowing financing (DOBF) has positive significant impact on 
Health sector GDP (HGDP) because their observed values of $t$ - statistics (2.1711) was greater than its critical value (1.684). The External borrowing financing (EXBF) has negative insignificant impact on Health sector GDP (HGDP) because their observed values of $t$ - statistics $(-1.2746)$ was less than its critical value (1.684). The Term of trade (TOT) has negative insignificant impact on Health sector GDP (HGDP) because their observed values of $t$ - statistics (-1.4993) was greater than its critical value (1.684). The result of the $\mathrm{F}$ - statistical test shows that the overall regression of the variables was statistically insignificance. This is because observed values of the F - statistics (1.550) was less than its critical value (3.830). Again, our empirical result shows that the R-squared $\left(\mathrm{R}^{2}\right)$ is 0.5149 . The ECM statistics was (0.4914). The ECMt-1 result indicates that $49 \%$ numbers of errors have been corrected from short run adjustment to the long run. In other words, ECM statistics shows that the model has 49 percent degree of adjustment from short-run to long-run equilibrium.

Table 3 Empirical Results of the error correction Model (ECM)

\begin{tabular}{|c|c|c|c|c|}
\hline \multicolumn{5}{|c|}{ Dependent Variable: D(HGDP,1) } \\
\hline \multicolumn{5}{|c|}{ Method: Least Squares } \\
\hline \multicolumn{5}{|c|}{ Date: $01 / 10 / 20$ Time: $13: 37$} \\
\hline \multicolumn{5}{|c|}{ Sample (adjusted): 19812018} \\
\hline \multicolumn{4}{|c|}{ Included observations: 38 after adjustments } & \\
\hline Variable & Coefficient & Std. Error & t-Statistic & Prob. \\
\hline $\mathrm{C}$ & 17375.00 & 9214.540 & 1.885606 & 0.0691 \\
\hline $\mathrm{D}(\mathrm{GOBD}, 1)$ & 0.083222 & 0.146945 & 0.566345 & 0.5754 \\
\hline D(HARE,1) & 0.540616 & 0.201571 & 2.682012 & 0.0036 \\
\hline D(HECE,1) & 0.470044 & 0.468998 & 1.002230 & 0.0938 \\
\hline $\mathrm{D}(\mathrm{DOBF}, 1)$ & 0.143281 & 0.065994 & 2.171115 & 0.0380 \\
\hline $\mathrm{D}(\mathrm{EXBF}, 1)$ & -0.010724 & 0.008413 & -1.274693 & 0.0903 \\
\hline $\mathrm{D}(\mathrm{TOT}, 1)$ & -0.025131 & 0.016761 & -1.499320 & 0.1442 \\
\hline ECM-1 & -0.491469 & 0.127617 & -3.851130 & 0.0006 \\
\hline R-squared & 0.514996 & \multicolumn{2}{|c|}{ Mean dependent var } & 25901.81 \\
\hline Adjusted R-squared & 0.401828 & \multicolumn{2}{|c|}{ S.D. dependent var } & 64239.31 \\
\hline S.E. of regression & 49683.71 & \multicolumn{2}{|c|}{ Akaike info criterion } & 24.64941 \\
\hline Sum squared resid & $7.41 \mathrm{E}+10$ & \multicolumn{2}{|c|}{ Schwarz criterion } & 24.99416 \\
\hline Log likelihood & -460.3387 & \multicolumn{2}{|c|}{ Hannan-Quinn criter. } & 24.77207 \\
\hline F-statistic & 1.550729 & \multicolumn{2}{|c|}{ Durbin-Watson stat } & 1.905872 \\
\hline Prob(F-statistic) & 0.091471 & & & \\
\hline
\end{tabular}

\subsection{Econometric/Second Order Test}

The null hypothesis; there is Autocorrelation.

The Breuch-Godfrey Serial correlation LM Test was used to identify whether the model suffers from autocorrelation problem. The autocorrelation problem violates of ordinary least square assumption that says there is no correlation among error terms of different observation. Breuch-Godfrey Serial correlation LM Test is a statistic that ensures that the assumption of ordinary least square was not violated. The null hypothesis; there is autocorrelation problem. The result of Breuch-Godfrey Serial correlation LM Test (32.30083) and it P-value was (0.0000). Because Breuch-Godfrey Serial correlation LM Test (32.30083) was greater than its P-value was (0.0000), we conclude that the model is free from Autocorrelation problem. This denotes that prediction base of the Ordinary Least Square estimates were efficient and unbias. 
Table 4 Result of Breuch-Godfrey Serial Correlation LM Test

\begin{tabular}{|c|c|c|c|}
\hline \multicolumn{4}{|l|}{ Test Equation: } \\
\hline \multicolumn{4}{|c|}{ Dependent Variable: RESID } \\
\hline \multicolumn{4}{|c|}{ Method: Least Squares } \\
\hline \multicolumn{4}{|c|}{ Date: $01 / 10 / 20$ Time: $15: 30$} \\
\hline \multicolumn{4}{|c|}{ Sample: 19812018} \\
\hline \multicolumn{4}{|c|}{ Included observations: 38} \\
\hline \multicolumn{4}{|c|}{ Presample missing value lagged residuals set to zero. } \\
\hline \multicolumn{4}{|c|}{ Breusch-Godfrey Serial Correlation LM Test: } \\
\hline F-statistic & 32.30083 & Prob. $F(1,29)$ & 0.0000 \\
\hline Obs*R-squared & 20.02308 & Prob. Chi-Square(1) & 0.0000 \\
\hline
\end{tabular}

\subsection{Result of Ramsey Reset Test}

The null hypothesis; there is Specification Error.

Table 5 Result of Ramsey Reset Test

\begin{tabular}{|c|c|c|c|}
\hline \multicolumn{4}{|l|}{ Ramsey RESET Test } \\
\hline \multicolumn{4}{|c|}{ Equation: UNTITLED } \\
\hline \multicolumn{4}{|c|}{ Specification: D(HGDP,1) C D(GOBD,1) D(HARE,1) D(HECE,1) D(DOBF,1) } \\
\hline \multicolumn{4}{|c|}{$\mathrm{D}(\mathrm{EXBF}, 1) \mathrm{D}(\mathrm{TOT}, 1) \mathrm{ECM}-1$} \\
\hline \multicolumn{4}{|c|}{ Omitted Variables: Squares of fitted values } \\
\hline & Value & Df & Probability \\
\hline t-statistic & 9.022751 & 29 & 0.0000 \\
\hline F-statistic & 81.41003 & $(1,29)$ & 0.0000 \\
\hline Likelihood ratio & 50.80240 & 1 & 0.0000 \\
\hline \multicolumn{4}{|l|}{ F-test summary: } \\
\hline & Sum of Sq. & $\mathrm{Df}$ & Mean Squares \\
\hline Test SSR & $5.46 \mathrm{E}+10$ & 1 & $5.46 \mathrm{E}+10$ \\
\hline Restricted SSR & $7.41 \mathrm{E}+10$ & 30 & $2.47 \mathrm{E}+09$ \\
\hline Unrestricted SSR & $1.95 \mathrm{E}+10$ & 29 & $6.71 \mathrm{E}+08$ \\
\hline \multicolumn{4}{|l|}{ LR test summary: } \\
\hline & Value & Df & \\
\hline Restricted LogL & -460.3387 & 30 & \\
\hline Unrestricted LogL & -434.9375 & 29 & \\
\hline
\end{tabular}

This second order test checks whether the model of the study suffers model specification error. The null hypothesis; there is model specification error. The Ramsey reset test showed that there was no specification error because its Fstatistics (81.41003) is greater than Probability value (0.0000). It means that model include core variables in the model, does not include superfluous variables, the functional form of the model was very well chosen, there is no error of measurement in the regressand and regressor.

\subsection{Histogram Normality Test}

Normality test is done to check if the residuals of the error term have a normal distribution. Normality test is conducted using Jacques-Bera (JB) test. In testing for normality, approach used by Paavola (2006) for testing normality using Jacques-Bera test was adopted. 


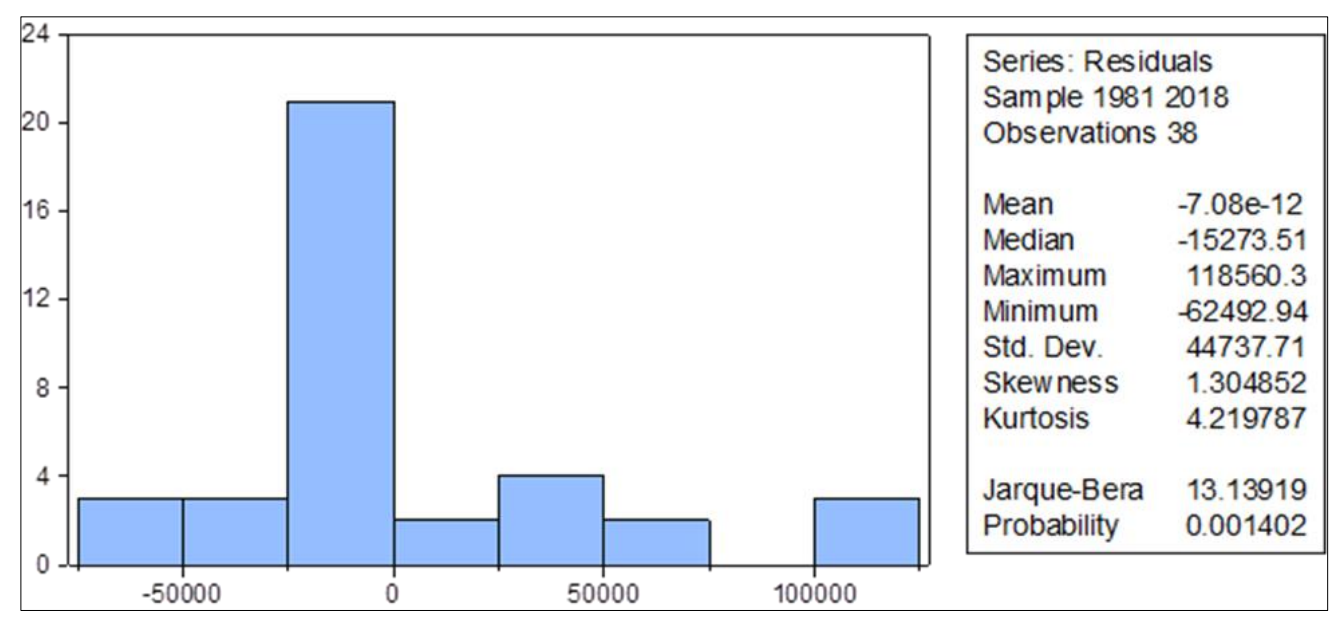

Figure 1 Presents Normality test for each of the Distribution; (Sources: E-view 9.0 Version)

Jarque-Bera (JB) test is statistics that compute both skewness and Kurtosis. Skewness shows the degree symmetry (normal distribution). The normal measurement is zero/0. Kurtosis is a statistic that compute degree of peakedness. The normal measurement is three/3. A distribution is skewed if one of its tails is longer than the other. A skewed distribution can be positive or negative. Positive skewed distribution means that it has a long tail in the positive direction. Negative skewed distribution means that it has a long tail in the negative direction.

The null hypothesis is that there is no skewness and Kurtosis in the model. We reject the null hypothesis because the Jarqua-Bera statistics (13.13919) is greater than probability value (0.000). We reject null hypothesis and accept the alternative that there is no skewness and Kurtosis in the model. The skewness is normal because the value was 1.304852. The model of the study produced positive skewed distribution meaning that it has a long tail in the positive direction. The kurtosis was 4.219787 meaning that the degree of peakedness was high that normal value of three (3). This implies that the standardized residuals from the estimated model in the regression framework is normally distributed, which is consistent with the OLS assumption.

\section{Summary of Findings}

The following are the major findings of the study:

- Government budget deficits have positive insignificant impact on public health sector output in Nigeria $(\mathrm{t}$ statistics $(0.5663)<t_{0.05}(1.684)$. Government budget deficits have 8 percent positive insignificant impact on public health sector output in Nigeria. A percent change in Government budget deficits result to 8 percent increase in public health sector output in Nigeria.

- External borrowing of financing budget deficits has negative insignificant impact on Health sector output in Nigeria ( $\mathrm{t}$ - statistics $(-1.2746)<\mathrm{t}_{0.05}(1.684)$. External borrowing of financing budget deficits has 1 percent negative insignificant impact on public health sector output in Nigeria. A percent change in External borrowing of financing budget deficits result to 1 percent decrease in public health sector output in Nigeria.

- Domestic borrowing of financing budget deficits has positive significant impact on Health sector output in Nigeria ( $\mathrm{t}$ - statistics (2.1711) $>\mathrm{t}_{0.05}$ (1.684). Domestic borrowing of financing budget deficits has 14 percent positive significant impact on public health sector output in Nigeria. A percent change in Domestic borrowing of financing budget deficits result to 14 percent increase in public health sector output in Nigeria.

\section{Conclusion}

This study concludes that the government budget deficits have positive insignificant impact on Health sector output in Nigeria because more budget allocations are put in health recurrent government expenditure than health capital expenditure which is the engine growth of health sector output. Our findings reveal that healthcare services in Nigeria have been, and are still very poor. As Nigeria's population continues to grow rapidly, emerging health dynamics are equally occurring at the same rate, meaning the country's health system must adapt. Sadly, Nigeria's health sector as is cannot cater to its growing population, much less keep up with rapid changes within the sector at regional, continental and global levels. 
A pervasive lack of adequate health infrastructure continues to stall basic healthcare delivery. Where facilities are available, they are often obsolete, and funds to equip existing hospitals are spread thin. This has perpetuated constant friction between government and health workers, resulting in strike actions that continually plague the health system at community, state and federal level.

\section{Recommendations of the Study}

Based on the findings of this study, the following recommendations were made.

- The Federal Government should start and sustain implementation of the National Health Act. Allocations made to the Basic Health Care Provision Fund (BHCPF) should be drawn directly from the National Health Act, which seeks no less than 1\% of the Consolidated Revenue Fund of the Federation - and is to come from the FG's share of revenue. Funds should be part of statutory transfers, to safeguard their withdrawal, disbursement and audit. This is because the 2018 Budget did not make any provision recognising the National Health Act as a statutory payment. If wholly implemented, this $1 \%$ of the CRF would be worth an estimated N60.6bn raising funding for the health sector each year.

- The Federal Government should start and sustain implementation counterpart funds that worth N33.5bN in health sector in order to close the funding gap and fulfill her co-financing obligations towards GAVI (Global Alliance for Vaccines and Immunization). The fund is needed to reduce vaccine-preventable deaths in Nigeria. Nigeria should include a provision of N33.5bn $(\$ 110 \mathrm{mn})$ for vaccine procurement. The Federal Government should make efforts to put internal and external audit control to checkmate careless spending and enhance proper accountability.

- Government should adopt fiscal adjustment mechanism that increases revenue through improved taxes rather than borrowing to finance budget deficit and dependence on crude oil revenue. Government should revive rundown government companies and levy corporate income from the company and excise tax from their product to have enormous capacity to increase revenue from taxes to finance her fiscal expenditures. This would lessen the over reliance on public borrowing to finance government expenditures.

\section{Compliance with ethical standards}

\section{Disclosure of conflict of interest}

No conflict of interest among the Authors

\section{References}

[1] Oluwafadekemi A, Ogundipe AA. Fiscal Deficit and Economic Growth in Nigeria: Ascertaining a Feasible Threshold International Journal of Economics and Financial Issues. 2018; 8(3): 296-306.

[2] Tung LT. The effect of fiscal deficit on economic growth in an emerging economy: Evidence from Vietnam. Journal of International Studies. 2018; 11(3): 191-203.

[3] Folorunso BA, Falade OE. Relationship between fiscal deficit and public Debt in Nigeria: An error correction approach. Journal of Economics and Behavioral Studies. 2013; 5(6): 346-355.

[4] Ubi P, Inyang J. Fiscal Deficit and Nigeria's Economic Development International Journal of Economics, Commerce and Management United Kingdom. May 2018; VI(5).

[5] Vincent NE, Clem IN. Fiscal deficits and private investment: Econometric evidence from Nigeria. International Journal of Innovative Research in Management. 2013; 3(2): 1-18.

[6] Yaqub FH, Ojapinwa HJ and Yussuff, B. Implication of Deficit Financing On Economic Growth in Nigeria European Journal of Accounting, Auditing and Finance Research; June 2012; 2 (10); 122-135.

[7] Idowu DO. The Impact of Health on Economic Growth in Nigeria Journal of Economics and Sustainable Development. 2014; 5(19).

[8] Eme 0, Okala UA, Uche IB. Building a Solid Health Care System in Nigeria: Challenges and Prospects Academic Journal of Interdisciplinary Studies MCSER Publishing, Rome-Italy. November 2014; 3(6).

[9] Anyanwaokoro M. Elements of public finance, Enugu, NG: Hosanna Publications. 2004. 
[10] Maji A, Achegbulu J0. The impact of fiscal deficit on economic growth in Nigeria. International Journal of Business and Management. 2012; 4(2): 127- 132.

[11] Okoye LU, Evbuomwan GO, Modebe NJ, Efobi U. Fiscal Deficits and Macroeconomic Performance in Nigeria IOSR Journal of Economics and Finance (IOSR-JEF). May-Jun. 2017; 4(3): 39-55.

[12] Ayadi FS, Ayadi FO. Impact of budget deficit on economic performance: A comparative study of Nigeria and south Africa Journal of Sustainable Development in Africa. 2008; 6(3): 191-203.

[13] Kosimbei GK. Budget deficit and macroeconomic performance in Kenya: An empirical analysis, doctoral thesis, Kenyatta University, Nairobi, KE. 2009.

[14] Ogunmuyiwa MS. Does Budget deficit Promote Economic Performance? Current Research Journal of Economic Theory. 2011; 3(1): 29-35.

[15] Saeidi P, Valizadeh Y. Impact of budget deficit on inflation and unemployment in Iran's economy. Journal of Basic and Applied Scientific Research. 2012; 2(7): 6979 - 6985.

[16] Ekperiware MC, Oladeji SI. Budget deficit Relief and Economic Performance in Nigeria: Journal of Economic and Sustainable Development. 2012; 3(8).

[17] Sulaiman LA, Azeez BA. Effect of Budget deficit on Economic Performance in Nigeria Current Research Journal of Economic Theory. 3(1): 29-35.

[18] Faraji K, Makame S. Impact of Budget deficit on Economic Performance: A Case Study of Tanzania. Advances in Management and Applied Economics. 2013; 3(4): 59-82.

[19] Joseph C, Uma K. relationship between budget deficit and interest rate: evidence from Nigeria. Arabian Journal of Business and Management Review (OMAN Chapter). 2013; 1(10).

[20] Wosowei TG. Budget defect and economic performance in Nigeria Saudi Journal of Business and Management Studies. 2013; 2(3): 25-31.

[21] Umeora CE. Analysis of the relationship between fiscal deficits and selected macroeconomic variables in Nigeria. Journal of Business and Management. 2013; 12(6): 19 - 27.

[22] Onuorah AC, GN Ogbonna. Deficit financing and the growth of Nigeria economy. International Journal of Management Sciences and Business Research. 2013; 3(2): 1-15.

[23] Odhiambo SO, Momanyi G, Othuon L, Aila FO. The Relationship between Fiscal Deficits and Economic Growth in Kenya: An Empirical Investigation. Greener Journal of Social Sciences. 2013; 3(6): 306-323.

[24] Ojong CM, Owuiz HO, Effiong C. Effect of budget deficit financing on the development of the Nigerian economy. European Journal of Business Management. 2013; 5(3): 61 - 83.

[25] Osuka BO, Achinihu JC. The impact of budget deficits on macroeconomic variables in the Nigerian economy. International Journal of Innovation Education and Research. 2014; 2(11): 164 - 183.

[26] Nkalu CN. The effects of budget deficits on selected macroeconomic variables in Nigeria and Ghana. Asian Journal of Empirical Research. 2015; 5(10): 167 - 180.

[27] Agu SU, Okwo IM, Ugwunta OD, Idike D. Fiscal Policy and Economic Growth in Nigeria: Emphasis on Various Components of Public Expenditure. SAGE Open. October-December 2015; 1-12.

[28] Osoro S. Effects of Budget Deficit in Economic Growth in Kenya Research Project Submitted in Partial Fulfillment of the Requirements for the award of the Degree of Master of Arts in Economics of the University of Nairobi. October 2016.

[29] Momodu AA, Monogbe TG. Budget Deficit and Economic Performance in Nigeria, Saudi Journal of Business and Management Studies Scholars Middle East Publishers Dubai, United Arab Emirates. 2017; 2(3B): 312-321.

[30] Nwaeze NC. Fiscal Deficit, Financing Options and Macroeconomic Stability in Nigeria: A Disaggregated Approach Greener Journal of Economics and Accountancy. September 2017; 6(2): 043-064.

[31] Dantama YU, Gatawa NM, Galli SM. An Analysis of the Impact of Fiscal Deficit on Private Investment in Nigeria: A Keynesian Perspective International Journal of Humanities and Social Science Invention. 2017; 6(4): 10-16.

[32] Ayogueze NF, Anidiobu GA. Assessment of Impact of Government Budget Deficits on Unemployment Rate in Nigeria. IOSR Journal of Economics and Finance (IOSR-JEF). Nov-Dec 2017; 8(6): 18-26. 
[33] Behera DB, Dash U. The impact of macroeconomic policies on the growth of public health expenditure: An empirical assessment from the Indian states. Cogent Economics \& Finance. 2018; 6(3): 191-203.

[34] Jibir A, Aluthge C. Modelling the determinants of government expenditure in Nigeria Journal of Cogent Economics \& Finance. 2019; 7: 1620154.

[35] Nwanna FO, Umeh GN. Deficit Financing and Economic Growth: The Nigerian Experience IIARD -International Journal of Economics and Financial Management. 2019; 4(1). 